\title{
Modulation of low-dose streptozotocin-induced diabetes in mice by administration of antibodies to I-A, I-E and I-J determinants
}

\author{
U. Kiesel ${ }^{1}$, M.Oschilewski ${ }^{1}$, M. Taniguchi ${ }^{2}$ and H. Kolb ${ }^{1}$ \\ ${ }^{1}$ Diabetes Research Institute, University of Düsseldorf, FRG, and ${ }^{2}$ Department of Immunology, School of Medicine, Chiba University, Japan
}

Summary. In male mice of strains $\mathrm{C} 3 \mathrm{H}$ and $\mathrm{C} 57 \mathrm{BL} / 6$ an experimental immune-mediated diabetes can be induced by multiple low doses of streptozotocin. The delay and partial suppression of hyperglycaemia after anti-I-A monoclonal antibody administration was dose dependent. Even saturation levels of anti-I-A did not cause complete protection from diabetes development. Administration of anti-I-E monoclonal antibody also significantly delayed the onset of hyperglycaemia. Surprisingly, the combined treatment with anti-I-A and anti-I-E did not result in better protection from diabetes. Thus, there is an I-A and I-E independent component of the disease. Furthermore, there is no restriction to either I-A or I-E. Anti-I-A was only effective when given at the beginning of the experiment, which implies that I-A molecules have a primary function during the induction of diabetes. The contribution of $\mathrm{I}-\mathrm{J}$ to the disease process is different. Administration of a polyspecific alloantiserum to I-J almost completely prevented hyperglycaemia. Injections of monospecific antibodies to I-J determinants enhanced hyperglycaemia, especially when given after the induction of diabetes. This indicates that I-J is involved in initial as well as in later stages of the disease process.

Key words: Experimental diabetes, mice, streptozotocin, antiIa-antibodies, major histocompatibility complex, immunomodulation.
In the past few years in vivo therapy of experimental autoimmune diseases with (monoclonal) antibodies to immune response gene products has received some attention [1]. Particularly, antibodies to I-A gene products were shown to suppress the immune response to acetylcholine receptor $[2,3]$, thus preventing the development of myasthenia gravis. A similar effect of such antibodies was demonstrated in experimental autoimmune encephalomyelitis [4]. In the latter case, suppression even of the ongoing disease could be achieved [5]. Administration of Ia antibodies in $(\mathrm{NZB} \times \mathrm{NZW}) \mathrm{F}_{1}$ with lupus-like nephritis resulted in an increased survival rate with no further deterioration of proteinurea [6]. Murine type II collagen induced arthritis as well as experimental autoimmune thyroiditis could also be suppressed by treatment with anti-Ia antibody [7, 8].

In a previous paper [9] we demonstrated that administration of monoclonal antibodies to I-A and of an alloantiserum to I-J partially suppressed the development of diabetes in mice treated with low doses of streptozotocin. Treatment with an H-2 alloantiserum (probably containing Ia antibodies) also partially preserved B-cell function and B-cell mass [10]. The B-cell toxin streptozotocin, when given in multiple low doses causes, in susceptible mice, a form of diabetes resembling human Type 1 (insulin-dependent) diabetes [11, 12]. The animal model is characterized by progressive B-cell loss with concomitant insulitis, resulting in hyperglycaemia and hypoinsulinaemia. The disease in mice is controlled by genes both within and outside the major histocompatibility complex [13, 14]. Diabetes development seems to be immune-mediated since anti-lymphocyte serum [15] as well as administration of monoclonal antibodies to T lymphocytes [16-18] prevents the disease.

In the present communication we have investigated the effect of time and dose dependency of the injection of monoclonal antibodies to I-A gene products, the complementary effect of antibodies to I-A and I-E gene products as well as the influence of monoclonal antibodies to I-J, on the course of low-dose streptozotocin induced diabetes.

\section{Materials and methods}

\section{Mice}

Male mice of strains C3H/HeHan $\left(\mathrm{H}-2^{\mathrm{k}}\right)$ and C57BL/6J/Bom $\left(\mathrm{H}-2^{\mathrm{b}}\right)$ were obtained from the Zentralinstitut für Versuchstierzucht (Hannover, FRG) and from Gl. Bomholtgard Ltd. (Ry, Denmark), respectively. The animals had free access to water and standard pellet diet (“ssniff M", Ssniff Co., Soest, FRG).

\section{Streptozotocin treatment}

Eight to 14-weeks-old mice were treated with five doses of $40 \mathrm{mg}$ streptozotocin (Boehringer, Mannheim, FRG) per kg body weight on consecutive days [11].

\section{Antibody treatment}

The monoclonal antibody to I-A ${ }^{\mathrm{k}}$ gene products (clone $\mathrm{H} 116-32 . \mathrm{R} 5$, IgG 2b; Camon, Wiesbaden, FRG) was specific for the determinant Ia.m6/Ia.19. In pilot experiments this antibody was selected as being the only one among three anti-I-A monoclonals to cause reproducible suppression of diabetes development in the low-dose streptozotocin 


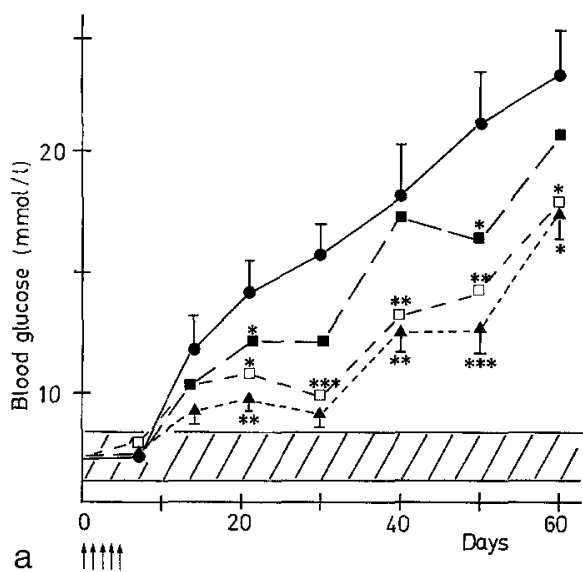

Fig. 1. a Dose response of anti-I-A ${ }^{k}$ monoclonal antibody on the development of hyperglycaemia (mean $\pm \mathrm{SEM}$ ) in $\mathrm{C} 3 \mathrm{H}$ mice when injected at day 0 . (@) $5 \times 40 \mathrm{mg}$ streptozotocin $/ \mathrm{kg}(n=42)$; ( $\mathbf{\square})$ streptozotocin plus $5 \mu \mathrm{l}$ ascites $(n=10)$; ( $\square$ ) streptozotocin plus $20 \mu \mathrm{l}$ ascites $(n=10) ;(\Lambda)$ streptozotocin plus $80 \mu \mathrm{l}$ ascites $(n=10) . *=p<0.05$; $* *=p<0.01 ; * * *=p<0.001$. Hatched area $=$ mean of untreated control mice $+3 \mathrm{SD}$. The arrows indicate the days of streptozotocin injections. b Suppression of hyperglycaemia by anti-I-A ${ }^{k}$ monoclonal antibody when injected at day 8 or in multiple doses of $20 \mu \mathrm{l}$. (O) $5 \times 40 \mathrm{mg}$ streptozotocin $/ \mathrm{kg}(n=42) ;(\mathbb{\square})$ streptozotocin plus anti-I$\mathrm{A}^{\mathrm{k}}$ injected at days $0,7,14$, and $21(n=10) ;(\boldsymbol{\Lambda})$ streptozotocin plus anti-I- $\mathrm{A}^{\mathrm{k}}$ injected at days $-2,0$ and $2(n=10)$. For further information see a. c Dose response of anti-I-A ${ }^{\mathrm{k}}$ monoclonal antibody on the course of hyperglycaemia (mean $\pm \mathrm{SEM}$ ) in $\mathrm{C} 3 \mathrm{H}$ mice when injected at day 8 and effect of combined administration of anti-I- $\mathrm{A}^{\mathrm{k}}$ with antiI-E $\mathrm{E}^{\mathrm{k}}$ monoclonal antibodies injected at day 0 . (O) $5 \times 40 \mathrm{mg}$ streptozotocin $/ \mathrm{kg}(n=42) ;(\square)$ streptozotocin plus $5 \mu 1$ ascites of anti-I-A at day $8(n=10) ;(\square)$ streptozotocin plus $20 \mu \mathrm{l}$ ascites of anti-I-A at day 8 $(n=10)$; ( $\mathbf{\Lambda})$ streptozotocin plus $80 \mu$ ascites of anti-I-A at day 8 $(n=10) ;(O)$ streptozotocin plus $20 \mu \mathrm{l}$ ascites of anti-I-A at day 0

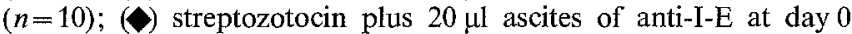
$(n=10) ;(\diamond)$ streptozotocin plus combined administration of $20 \mu \mathrm{l}$ of each anti-I-A and anti-I-E at day $0(n=10)$. For further information see a

model. The monoclonal IgG $2 \mathrm{a}$ antibody against $\mathrm{I}-\mathrm{E}^{\mathrm{k}}$ gene products was specific for the determinant la.m7 (clone 13/4.R5, Camon). Three monoclonal antibodies against $\mathrm{I}^{-\mathrm{J}^{\mathrm{b}}}$ determinants (clones E10 (IgG 2a), F4 (IgG 2b) and H6 (IgG 2a)) were prepared as described [19]. All monoclonal antibodies were used as ascites fluid.

An alloantiserum was prepared by immunization of mice against $\mathrm{I}^{-\mathrm{J}^{\mathrm{k}}}$ (lot J002, Camon).

In all experiments ascites fluid or antisera were diluted with distilled water to a final volume of $200 \mu \mathrm{l}$ and injected into the retro-orbital vein plexus. In those cases where antibody and streptozotocin should be administered the same day, the antibody was injected two $h$ before the drug to avoid any interference.

\section{Blood glucose determination}

Blood glucose values were determined from unfasted mice between 09.00 and 10.00 hours. Mice were bled from the tail and glucose concentrations measured by the hexokinase method (Gluco-quant, Boehringer Mannheim). All values were expressed in mmol/l.

\section{Statistical analysis}

The arithmetic means of blood glucose concentrations \pm S.E.M. were calculated on all experimental groups. Statistical differences were evaluated by Mann-Whitney rank test.

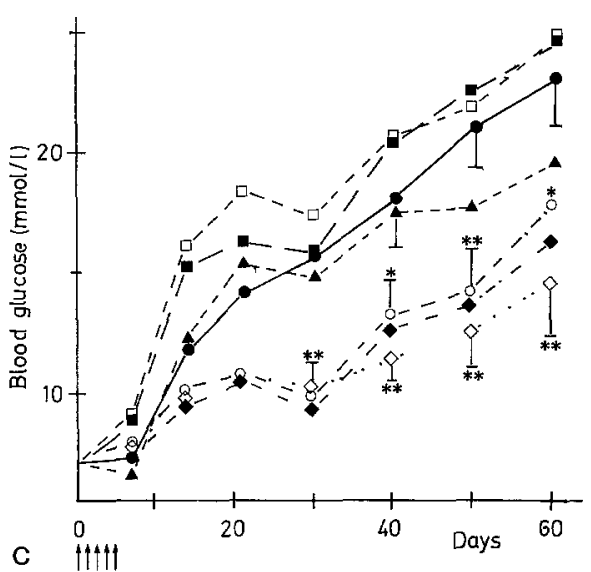

Results

Treatment of male $\mathrm{C} 3 \mathrm{H}\left(\mathrm{H}-2^{\mathrm{k}}\right)$ mice with multiple lowdose streptozotocin caused the development of hyperglycaemia around day 14, and a continuous rise in blood glucose levels until day 60 (Fig. 1 a). The administration of $20 \mu \mathrm{l}$ of anti-I-A antibody at day 0 did not cause complete protection from diabetes development, but resulted in a delay of hyperglycaemia and lower mean blood glucose levels at all times $(p<0.05$ or $p<0.001$ for days 14-60). Injection of $5 \mu$ l of antibody did not significantly retard diabetes development, demonstrating dose dependency (Fig. 1 a). The later occurrence of (milder) hyperglycaemia after anti-I-A antibody administration could not be suppressed by increasing antibody dose ( $80 \mu \mathrm{l}$, Fig. 1 a), by multiple early injections (at days $-2,0,2)$ nor by weekly injections during the first month (Fig. 1 b).

Administration of anti-I-A antibody was not effective when given after induction of the disease process, i.e. after completion of low-dose streptozotocin treatment. At this point, (day 8) neither low nor high amounts of anti-I-A antibody altered the course of hyperglycaemia development (Fig. 1 c).

$\mathrm{C} 3 \mathrm{H}$ mice express gene loci coding for different class II major histocompatibility antigens I-A and I-E. The administration of monoclonal antibodies to I-E delayed the onset of hyperglycaemia with similar kinetics as for anti-I-A (Fig.1 c). Combination of the two antibodies showed neither an additive nor a synergistic effect (Fig. 1 c).

A third phenotype, of which the expression is controlled by the class II major histocompatibility complex region, is I-J. In contrast to anti-I-A or anti-I-E antibodies, administration of an allo-antiserum to $I-J^{k}$ almost completely protected from hyperglycaemia (Table $1 \mathrm{~A})$. Again, antiserum injected after the start of streptozotocin treatment did not prevent diabetes development. Injections of anti-I-J at days 5 or 8 even slightly enhanced hyperglycaemia $(p<0.05$ at days 14,30 or 60 respectively).

Enhancement, in most cases, rather than suppression of diabetes development, was noted when three different monoclonal antibodies to $\mathbf{I}-\mathrm{J}^{\mathrm{b}}$ were tested ac- 
Table 1. Effect of treatment with antibodies to I-J on the development of hyperglycaemia (mmol/l, mean \pm SEM) when injected on different days: A Effects of alloantiserum to $\mathrm{I}-\mathrm{J}^{\mathrm{k}}(40 \mu \mathrm{l})$ in male $\mathrm{C} 3 \mathrm{H}$ mice; B Effects of 3 different monoclonal antibodies to I- $\mathrm{J}^{\mathrm{b}}$ ( $25 \mu \mathrm{l}$ ascites) in C57Bl/ 6 mice

\begin{tabular}{|c|c|c|c|c|}
\hline & & Day 14 & Day 30 & Day 60 \\
\hline $\begin{array}{l}\mathbf{A} \\
S Z^{d}\end{array}$ & 42 & $12.9 \pm 0.8$ & $16.9 \pm 1.1$ & $21.9 \pm 1.3$ \\
\hline $\begin{array}{l}S Z^{\mathrm{d}}+\mathrm{I}-\mathrm{J}^{\mathrm{e}} \\
\text { day }-2\end{array}$ & 10 & $8.9 \pm 0.3^{b}$ & $10.9 \pm 1.0^{\mathrm{a}}$ & $8.8 \pm 0.6^{\mathrm{c}}$ \\
\hline $\begin{array}{l}\mathrm{SZ}^{\mathrm{d}}+\mathrm{I}-\mathrm{J}^{\mathrm{e}} \\
\text { day } 0\end{array}$ & 20 & $9.2 \pm 0.2^{\mathrm{c}}$ & $9.9 \pm 0.8^{b}$ & $10.5 \pm 1.2^{\mathrm{c}}$ \\
\hline $\begin{array}{l}S Z^{\mathrm{d}}+\mathrm{I}-\mathrm{J}^{\mathrm{e}} \\
\text { day } 2\end{array}$ & 10 & $12.3 \pm 0.9$ & $14.5 \pm 1.3$ & $19.1 \pm 1.8$ \\
\hline $\begin{array}{l}\mathrm{SZ}+\mathrm{I}-\mathrm{J}^{\mathrm{e}} \\
\text { day } 5\end{array}$ & 30 & $14.8 \pm 0.7^{\mathrm{a}}$ & $18.4 \pm 1.2$ & $26.6 \pm 1.6^{\mathrm{a}}$ \\
\hline $\begin{array}{l}\mathrm{SZ}^{\mathrm{d}}+\mathrm{I}-\mathrm{J}^{\mathrm{e}} \\
\text { day } 8\end{array}$ & 20 & $15.1 \pm 1.1$ & $20.0 \pm 2.4^{\mathrm{a}}$ & $25.2 \pm 2.9$ \\
\hline $\begin{array}{l}\text { B } \\
S Z^{d}\end{array}$ & 21 & $12.4 \pm 0.8$ & $16.1 \pm 1.1$ & $17.0 \pm 1.3$ \\
\hline $\begin{array}{l}\mathrm{SZ}+\mathrm{E} 10^{\mathrm{f}} \\
\text { day } 0\end{array}$ & 10 & $17.1 \pm 1.1^{\mathrm{b}}$ & $21.4 \pm 2.0^{\mathrm{b}}$ & $19.6 \pm 2.2$ \\
\hline $\begin{array}{l}\mathrm{SZ}+\mathrm{E} 10^{\mathrm{f}} \\
\text { day } 8\end{array}$ & 9 & $15.8 \pm 0.8^{b}$ & $21.0 \pm 0.8^{b}$ & $26.4 \pm 1.4^{\mathrm{c}}$ \\
\hline $\begin{array}{l}\mathrm{S} Z^{\mathrm{d}}+\mathrm{F} 4^{\mathrm{g}} \\
\text { day } 0 \\
\mathrm{~S} Z^{\mathrm{d}}+\mathrm{F} 4^{\mathrm{g}}\end{array}$ & 10 & $15.6 \pm 1.1^{\mathrm{a}}$ & $20.2 \pm 1.1^{\mathrm{a}}$ & $24.6 \pm 2.0^{\mathrm{b}}$ \\
\hline $\begin{array}{l}\mathrm{SZ}^{\mathrm{d}}+\mathrm{F}^{\mathrm{g}} \\
\text { day } 8\end{array}$ & 9 & $15.2 \pm 1.0^{\mathrm{a}}$ & $20.8 \pm 1.3^{b}$ & $20.0 \pm 1.6$ \\
\hline $\begin{array}{l}\mathrm{SZ}^{\mathrm{d}}+\mathrm{H} 6^{\mathrm{h}} \\
\text { day } 0\end{array}$ & 10 & $13.8 \pm 0.8$ & $14.2 \pm 1.3$ & $17.6 \pm 2.0$ \\
\hline $\begin{array}{l}\mathrm{SZ}^{\mathrm{d}}+\mathrm{H}^{\mathrm{h}} \\
\text { day } 8\end{array}$ & 9 & $15.5 \pm 1.1$ & $19.4 \pm 0.8$ & $23.8 \pm 1.2^{b}$ \\
\hline
\end{tabular}

${ }^{\mathrm{a}} p<0.05 ;{ }^{\mathrm{b}} p<0.01 ;{ }^{\mathrm{c}} p<0.001$ : significance refers to values obtained in the streptozotocin treated group (unmarked data are non significant); ${ }^{d} \mathrm{SZ}=5 \times 40 \mathrm{mg}$ streptozotocin per $\mathrm{kg}$ body weight; ${ }^{\mathrm{e}} \mathrm{I}-\mathrm{I}=\mathrm{al}-$ loantiserum to $\mathrm{I}-\mathrm{J}^{\mathrm{k}} ;{ }^{\mathrm{f}} \mathrm{E} 10=$ anti-I-J $^{\mathrm{b}}$ (clone E10); ${ }^{\mathrm{g}} \mathrm{F} 4=$ anti-I-J $^{\mathrm{b}}$ (clone $\mathrm{F} 4) ;{ }^{\text {h }} \mathrm{H} 6=$ anti-I-J ${ }^{\mathrm{b}}$ (clone $\mathrm{H} 6$ )

cording to the same protocol in C57BL/6J $\left(\mathrm{H}-2^{\mathrm{b}}\right)$ mice (Table 1B). Enhancement was more pronounced when antibodies were given 4 days after, rather than shortly before, streptozotocin injections (Table 1 B).

\section{Discussion}

The use of different antibodies to products controlled by the I-region of the major histocompatibility complex, and the variation of dose and treatment schedule in the present experiments, has led to further insight into the mechanisms involved in the development of immune diabetes.

Firstly, there is a dose dependence of the protective effect of anti-I-A monoclonal antibody. Maximum effect is reached with $20 \mu 1$ of the antibody, doses 2 or 4 times higher do not lead to a significantly higher outcome. This observation indicates the saturation of relevant binding site or transgression of a threshold binding level for anti-I-A antibodies.

It is of interest that "saturation" levels of anti-I-A antibodies, even when given repeatedly over one month did not provide complete protection from hyperglycaemia, but only induced a delay of diabetes development with subsequent milder hyperglycaemia. We would argue that part of the disease process is non-I-A dependent. This is in accord with previous observations that beside I-region genes, loci outside the major histocompatibility gene complex also contribute to disease susceptibility $[13,14]$. In this context it should be noted that the depletion of $T$ cells in the same model not only failed to completely prevent diabetes development, but resulted in a delayed onset of milder hyperglycaemia [17, 20]. Thus, there are I-A-independent and T cell-independent components to the disease. Such components may be the $T$ cell independent activity of macrophages $[17,21]$ or the late death of streptozotocin damaged B-cells [22].

The administration of anti-I-A was effective only when given early in the diabetes induction period. A primary function of I-A molecules, therefore, is during disease induction. It is improbable that anti-I-A acts on the level of islet B-cells. Although islet cells may express I-A antigens some time after streptozotocin injection [23], antibodies to I-A are effective when given before streptozotocin, i.e. at a time when islet cells are I-A negative.

I-A and I-E are separate molecular entities and it is surprising that anti-I-A gives similar protection from diabetes as anti-I-E, and that the two do not add up to better protection. In another model of insulin-dependent diabetes - the spontaneous autoimmune diabetic $\mathrm{BB}$ rat - it was found that repeated administration of an anti-I-E equivalent antibody but not of an anti-I-A antibody decreased the incidence rate of diabetes plus thyroiditis [24]. I-A and I-E generally act as restriction elements for different proteins, probably because the two receptors recognize different peptide motifs $[25,26]$. If I-A and I-E both act as restriction elements in the lowdose streptozotocin model one would expect more than one antigen (or peptide sequence) to be involved in the disease process. A contribution of both I-A and I-E to $\mathrm{T}$ cell autoimmunity was also found in experimental autoimmune encephalomyelitis [27].

Our results with anti-I-J antibodies show that highly effective immunomodulation can be reached by this approach. Results vary from complete protection with a conventional antiserum to I-J, to substantial enhancement by some monoclonal antibodies. Suppression was only seen when anti-I-J was given prior to diabetes induction. Enhancement was most marked when anti-I-J was administered after diabetes induction. I-J determinants are expressed on immunoregulatory $T$ cells and some macrophages, are linked in their genetic polymorphism to the major histocompatibility complex and have been implicated in the generation of suppressor, contrasuppressor and helper amplifier activities [28].

As described [29], there are two types of I-J: one is expressed on some $\mathrm{T}$ helper cells $\left(\mathrm{Th}_{2}\right)$ the other on suppressor $\mathrm{T}$ cells. Therefore, it is quite possible that the conventional antiserum contains two types of anti-I-J antibodies, whereas our monoclonal anti-I- $\mathrm{J}^{\mathrm{b}}$ antibodies recognize the idiotypic structure on suppressor 
$\mathrm{T}$ cells and are specific for them but not for $\mathrm{Th}_{2}$ cells [30]. Thus, treatment with these anti-I-J antibodies eliminates or suppresses suppressor $T$ cell activity and results in the enhancement of the disease.

Our results do not help to identify the nature of I-J antigens, except that by judging the contrasting effects of monoclonal antibodies to I-A, I-E versus I-J suggested that these molecules are not functionally similar.

In summary, the data indicate an important function of I-A, I-E and some I-J molecules early during diabetes development and the involvement of I-J also, at a later stage.

Acknowledgements. We thank Prof. Dr. Gries for his support, Mrs. L. Uebber and Mrs. G. Huppenkothen for their excellent technical assistance. This work was supported by the Bundesministerin für Jugend, Familie und Gesundheit, the Ministerin für Wissenschaft und Forschung des Landes Nordrhein-Westfalen and the Deutsche Forschungsgemeinschaft, Sonderforschungsbereich 113.

\section{References}

1. Steinberg AD, Santoro TJ (1984) Anti-Ia antibodies: a revolutionary therapy for immune-mediated diseases? Immunol Today 5: 13-14

2. Waldor MK, Stiram S, McDevitt HO, Steinman L (1983) In vivo therapy with monoclonal anti-I-A antibody suppresses immune responses to acetylcholine receptor. Proc Natl Acad Sci USA 80: 2713-2717

3. Christadoss P, Lindstrom J, Talal N (1983) Cellular immune response to acetylcholine receptors in murine experimental autoimmune myasthenia gravis: inhibition with monoclonal anti-I-A antibodies. Cell Immunol 81:1-8

4. Steinman L, Rosenbaum JT, Sriram S, McDevitt HO (1981) In vivo effects of antibodies to immune response gene products: prevention of experimental allergic encephalitis. Proc Natl Acad Sci USA $78: 7111-7114$

5. Sriram S, Steinman L (1983) Anti-I-A antibody suppresses active encephalomyelitis: treatment model for diseases linked to Ir genes. J Exp Med 158: 1362-1367

6. Adelmann NE, Watling DL, McDevitt HO (1983) Treatment of $(\mathrm{NZB} \times \mathrm{NZW}) \mathrm{F}_{1}$ disease with anti-I-A monoclonal antibodies. $\mathrm{J}$ Exp Med 158: 1350-1355

7. Wooley PH, Luthra HS, Lafuse WP, Huse A, Stuart JM, David CS (1985) Type II collagen-induced arthritis in mice. III. Suppression of arthritis by using monoclonal and polyclonal anti-Ia antisera. $J$ Immunol 134: 2366-2374

8. Vladutio AO, Steinman L (1987) Inhibition of experimental autoimmune thyroiditis in mice by anti-I-A antibodies. Cell Immunol 109: 169-180

9. Kiesel U, Kolb H (1983) Suppressive effect of antibodies to immune response gene products on the development of low-dose streptozocin-induced diabetes. Diabetes 32: 869-871

10. Bonnevie-Nielsen V, Lernmark $\AA$ (1986) An H-2 allo-antiserum preserves $\beta$-cell function in mice made diabetic by low-dose streptozocin. Diabetes 35: 570-573

11. Like AA, Rossini AA (1976) Streptozotocin-induced pancreatic insulitis: new model of diabetes mellitus. Science 193:415-417

12. Kolb H (1987) Mouse models of insulin dependent diabetes - low dose streptozotocin induced diabetes and non obese diabetic (NOD) mice. Diabetes Metab Rev 3: 751-778

13. Kiesel U, Kolb H (1982) Low-dose streptozotocin-induced autoimmune diabetes is under the genetic control of the major histocompatibility complex. Diabetologia 23: 69-71
14. Kiesel U, Falkenberg FW, Kolb H (1983) Genetic control of lowdose streptozotocin-induced autoimmune diabetes in mice. J Immunol 130: 1719-1722

15. Rossini AA, Williams RM, Appel MC, Like AA (1978) Complete protection from low-dose streptozotocin-induced diabetes in mice. Nature 276: 182-184

16. Kiesel U, Oschilewski M, Oschilewski U, Stünkel K, Opitz U, Kolb H (1984) Role of helper and suppressor lymphocytes and of macrophages in multiple dose streptozotocin-induced autoimmune diabetes. Diabetologia 27: 296 (Abstract)

17. Kantwerk G, Cobbold S, Waldmann H, Kolb H (1987) L3T4 and Lyt 2 cells are both involved in the generation of low-dose streptozotocin induced diabetes in mice. Clin Exp Immunol 70: 585-592

18. Herold KC, Montag AG, Fitch FW (1987) Treatment with anti-Tlymphocyte antibodies prevents induction of insulitis in mice given multiple doses of streptozocin. Diabetes 36: 796-801

19. Kanno M, Kobayashi S, Tokuhisa T, Takei I, Shinohara N, Taniguchi $M$ (1981) Monoclonal antibodies that recognize the product controlled by a gene in the I-J subregion of the mouse H-2 complex. J Exp Med 154: 1290-1304

20. Dayer-Metroz MD, Kimoto M, Izui S, Vassalli P, Renold AE (1988) Effect of helper and/or cytotoxic T-lymphocyte depletion on low-dose streptozocin-induced diabetes in $\mathrm{C} 57 \mathrm{BL} / 6 \mathbf{J}$ mice. Diabetes 37: 1082-1089

21. Kolb-Bachofen V, Epstein S, Kiesel U, Kolb H (1988) Low-dose streptozocin-induced diabetes in mice. Electron microscopy reveals single-cell insulitis before diabetes onset. Diabetes 37:21-27

22. Bolaffi JL, Nowlain RE, Cruz L, Grodsky GM (1986) Progressive damage of cultured pancreatic islets after single early exposure to streptozocin. Diabetes 35: 1027-1033

23. Campbell IL, Oxbrow L, Koulmanda M, Harrison LC (1988) IFN induces islet cell $\mathrm{MHC}$ antigens and enhances autoimmune, streptozocin-induced diabetes in the mouse. J Immunol 140: 1111-1116

24. Boitard C, Michie S, Serrurier P, Butcher GW, Larkins AP, McDevitt HO (1985) In vivo prevention of thyroid and pancreatic autoimmunity in the $\mathrm{BB}$ rat by antibody class II major histocompatibility complex gene products. Proc Natl Acad Sci USA 82: $6627-6631$

25. Benacerraf B, McDevitt HO (1972) The histocompatibility linked immune response genes. Science 175: 273-279

26. Buus S, Sette A, Colon SM, Miles C, Grey HM (1987) The relation between major histocompatibility complex (MHC) restriction and the capacity of Ia to bind immunogenic peptides. Science 235: $1353-1358$

27. Offner H, Brostoff S, Vandenbark AA (1986) Antibodies against I-A and I-E determinants inhibit the activation and function of encephalitogenic T-lymphocyte lines. Cell Immunol 100:364-373

28. Jaureguiberry B, Liao L, Kuchroo V, Dorf ME, Diamond B (1988) Monoclonal anti-idiotypic antibodies to an I-J interacting molecule inhibit suppression in an $\mathrm{H}-2$ restricted way. J Immunol 140: 3286-3289

29. Tada T, Takemori T, Okumura K, Nonaka M, Tokuhisa T (1978) Two distinct types of helper $T$ cells involved in the secondary antibody response: independent and synergistic effects of $\mathrm{Ia}^{-}$and $\mathrm{Ia}^{+}$helper T cells. J Exp Med 147: 446-458

30. Sumida T, Sado T, Kojima M, Ono K, Kamisaku H, Taniguchi M (1985) I-J as an idiotype of the recognition component of antigenspecific suppressor T-cell factor. Nature 31: 738-741

Received: 21 October 1988

and in revised form: 20 January 1989

Dr. U.Kiesel

Diabetes Research Institute

Auf'm Hennekamp 65

D-4000 Düsseldorf

FRG 